\title{
Dysembryoplastic Neuroepithelial Tumor (DNT): Morphological and Immunohistochemical Features
}

\author{
Jaudah A. Al-Maghrabi ${ }^{1,2}$ (MD, FRCPC) \\ Department of Pathology \\ ${ }^{1}$ Faculty of Medicine, King Abdulaziz University and \\ ${ }^{2}$ King Faisal Specialist Hospital \& Research Center, \\ Jeddah, Saudi Arabia \\ jalmaghrabi@hotmail.com
}

\begin{abstract}
Dysembryoplastic neuroepithelial tumor is a rare mixed neuronalglial tumor. The recognition and correct diagnosis of dysembryoplastic neuroepithelial tumor is important because this tumor is curable by excision. The records of the Pathology Department at King Faisal Specialist Hospital and Research Center, Jeddah, Saudi Arabia, were reviewed for cases that were histologically diagnosed as dysembryoplastic neuroepithelial tumor between 2000 and 2007; five cases were found. The clinical, radiological, histological and immunohistochemical findings were reviewed. The ages ranged between 9 and 25 years. There were 2 males and 3 females. All patients were diagnosed with epilepsy. Three patients had temporal tumor and the other two had frontal tumors. Radiological evaluation showed non-enhancing mass without mass effect or vasogenic edema. All five cases were characteristically composed of small round oligodendroglia-like cells, astrocytes and mature neurones in varying proportions. Immunocytochemistry for glial fibrillary acidic protein and neuronal markers (neuron-specific enolase; and synaptophysin) highlights the astrocytic and neuronal components. The recognition of this tumor is very important because it is a surgically curable lesion with excellent prognosis. Pathologists need to be familiar with the characteristic histopathological findings to avoid unnecessary overtreatment by radiotherapy or chemotherapy.
\end{abstract}

Keywords: Dysembryoplastic neuroepithelial tumor, Gliomas, Neuralglial tumor.

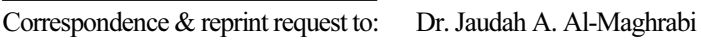

P.O. Box 80205, Jeddah 21589, Saudi Arabia
}

Accepted for publication: 25 September 2007. Received: 25 July 2007. 


\section{Introduction}

Dysembryoplastic neuroepithelial tumors (DNT) are rare mixed neuronal-glial tumors that should be differentiated from low-grade gliomas. They are usually supratentorial tumors occurring in children and young adult Males are more frequently affected ${ }^{[1]}$. The recognition and correct diagnosis of DNT is important because this tumor is curable by excision. In the recent WHO classification, DNT are considered a frequent cause of drug-resistant epilepsy ${ }^{[1]}$. The incidence in specimens resected from patients treated surgically for long-standing epilepsy varies, ranging from 12.6 to $56.3 \%$ in the large series ${ }^{[2,3]}$.

\section{Methods}

The records of the Pathology Department at King Faisal Specialist Hospital and Research Center (KFSH\&RC), Jeddah, Saudi Arabia (KSA), were reviewed for cases that were histologically diagnosed as DNT. The search covered the period between 2000 and 2007. KFSH\&RC is the main hospital in KSA for surgical treatment of epilepsy. Five cases were found. The clinical, radiological, histological and immunohistochemical findings were reviewed. Immunocytochemistry study was performed for glial fibrillary acidic protein (GFAP) (Dako, dilution: 1/100), neuron-specific enolase (Cell marque, dilution 1/250), synaptophysin (Cell marque, dilution 1/500), and neurofilament (Cell marque, dilution 1/200).

\section{Results}

The ages ranged between 9 and 25 years. There were 2 males and 3 females. All patients were diagnosed with epilepsy. Three patients had the tumor in the temporal lobe and two in the frontal lobe. Radiological evaluation using magnetic resonance imaging (MRI) and computerised tomography (CT scan) showed non-enhancing tumors without mass effect or vasogenic edema. Calcification was identified in two cases. The clinical presentation and radiological findings are summarised in Table 1. 
Table 1. Summary of the clinical and MRI results of the patients.

\begin{tabular}{|c|c|c|c|c|}
\hline Patients & Age/sex & Clinical presentation & Radiology & $\begin{array}{l}\text { Follow-up } \\
\text { period }\end{array}$ \\
\hline 1 & $12 \mathrm{Y} / \mathrm{F}$ & $\begin{array}{l}\text { Epilepsy with right } \\
\text { temporal tumor }\end{array}$ & $\begin{array}{l}\text { Tumor measures } 3.5 \mathrm{~cm} \\
\text { mass with cystic } \\
\text { component and without } \\
\text { enhancement. No mass } \\
\text { effect or vasogenic } \\
\text { edema. }\end{array}$ & $\begin{array}{l}7 \text { years. } \\
\text { Patient developed } \\
\text { a new lesion } 2 \\
\text { years after initial } \\
\text { diagnosis with } \\
\text { similar histology. } \\
\text { She had no other } \\
\text { recurrence over } \\
\text { the last } 5 \text { years }\end{array}$ \\
\hline 2 & $25 \mathrm{Y} / \mathrm{M}$ & $\begin{array}{l}\text { Epilepsy with right } \\
\text { frontal tumor }\end{array}$ & $\begin{array}{l}\text { Tumor measures } 4.2 \mathrm{~cm} \\
\text { mass without } \\
\text { enhancement with } \\
\text { calcification. No mass } \\
\text { effect or vasogenic } \\
\text { edema. It has } \\
\text { hyperintensity on T2. }\end{array}$ & $\begin{array}{l}31 / 2 \text { years } \\
\text { No recurrence }\end{array}$ \\
\hline 3 & $9 \mathrm{Y} / \mathrm{F}$ & $\begin{array}{l}\text { Epilepsy with left } \\
\text { frontal tumor }\end{array}$ & $\begin{array}{l}\text { Tumor measures } 5 \mathrm{~cm} \\
\text { without enhancement. } \\
\text { There is calcification } \\
\text { and scalloping effect on } \\
\text { the inner table. No mass } \\
\text { effect or vasogenic } \\
\text { edema. It has } \\
\text { hyperintensity on } \mathrm{T} 2 \text {. }\end{array}$ & $\begin{array}{l}1 \frac{1}{2} \text { years } \\
\text { No recurrence }\end{array}$ \\
\hline 4 & $14 \mathrm{Y} / \mathrm{F}$ & $\begin{array}{l}\text { Epilepsy with right } \\
\text { temporal tumor }\end{array}$ & $\begin{array}{l}\text { Tumor measures } 5.3 \mathrm{~cm} \\
\text { mass with cystic } \\
\text { component and without } \\
\text { enhancement. There is } \\
\text { calcification No mass } \\
\text { effect or vasogenic } \\
\text { edema. }\end{array}$ & $\begin{array}{l}2 \text { years. } \\
\text { No recurrence }\end{array}$ \\
\hline 5 & $15 \mathrm{Y} / \mathrm{M}$ & $\begin{array}{l}\text { Epilepsy with left } \\
\text { temporal tumor }\end{array}$ & $\begin{array}{l}\text { Tumor measures } 3.4 \mathrm{~cm} \\
\text { mass without } \\
\text { enhancement. No mass } \\
\text { effect or vasogenic } \\
\text { edema. It has } \\
\text { hyperintensity on T2. }\end{array}$ & $\begin{array}{l}1 \text { year. } \\
\text { No recurrence }\end{array}$ \\
\hline
\end{tabular}

The cases were characteristically composed of small round oligodendroglial-like cells (OLC), astrocytes and mature neurones in varying proportions (Fig. 1a-c). Immunocytochemistry for GFAP and neuronal markers (neuron-specific enolase, synaptophysin (Fig. 1d) and neurofilament) confirm the diagnosis and highlight the astrocytic and 
neuronal components. The response to surgery was excellent. One patient presented with a new lesion 2 years later with similar histological features; none of the other tumors have recurred, and the control of seizures remained good.
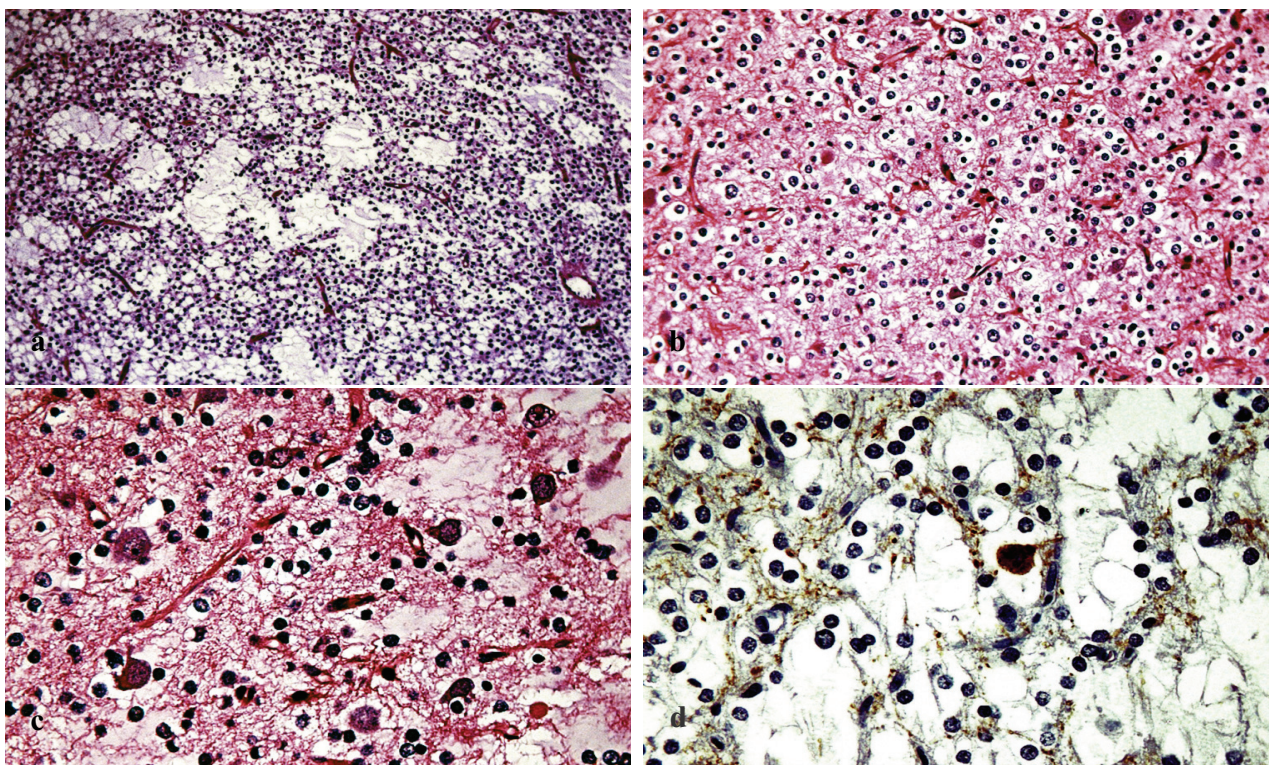

Fig. 1. a) Section from one of the tumors reveals mixed cells with mucoid areas. (Hematoxylen and Eosin stain, original power $\times 100$ ). b) A higher power reveals mainly small round oligodendroglia-like cells (OLC) with perinuclear halos (Hematoxylen and Eosin stain, original power $\times 200$ ). c) A higher power reveals a mixed pattern composed of oligodendroglia-like cells (OLC), astrocytes and scattered mature neurones (Hematoxylen and Eosin stain, original power $\times 400$ ). d) Immunohistochemistry stain for synaptophysin reveals positive staining in neuronal cells.

\section{Discussion}

King Faisal Specialist Hospital and Research Center in Jeddah is considered one of the main hospitals in KSA for surgery of epilepsy. Annually more than 30 surgical procedures are performed at this institution for the treatment of epilepsy. We recognized five cases of histologically proven DNT among those resections performed for treatment of epilepsy. DNT is now a well-known, seizure-producing entity that occurs characteristically in the cerebral cortex of children and young adults ${ }^{[4-12]}$. Daumas-Duport et al ${ }^{[9]}$ described DNT as having the 
following features: (1) intracortical location; (2) partially nodular structure; (3) mixed glial and neuronal composition, always with the socalled 'specific' glioneuronal element and finally, (4) the tumors were usually associated with some form of cortical dysplasia in the adjacent cortex. Additional reports have confirmed these features ${ }^{[4,6,7]}$. Our five patients have the above features. DNT, despite having a heterogeneous morphological appearance, are unified by their clinical presentation of drug-resistant epilepsy often with the onset in childhood ${ }^{[1]}$. In about $90 \%$ of cases, the first seizure occurs before 20 years of age ${ }^{[1]}$. Patients may present with seizures in adulthood. Four of the five patients were children below the age of 15 years; all of them presented with epilepsy that was drug resistant. The fifth patient was a 25 year old adult. The tumor has been reported in association with neurofibromatosis Type $1^{[13]}$. No recurrence was noted despite incomplete removal of the tumor in $71 \%$ of the cases ${ }^{[14]}$. Honavar et al. ${ }^{[15]}$ reported a follow-up for up to 15 years, and confirmed the indolent biological behaviour of this tumor. All of our patients showed the tumor in the cerebral cortex. DNT show a predilection for the temporal lobe ${ }^{[1]}$. Although most DNT occur in the cerebral cortex, reports are appearing about DNT in other locations, including the pons ${ }^{[16]}$, thalamus ${ }^{[16,17]}$, basal ganglia ${ }^{[16,18,19]}$, cerebellum $^{[16,20,21]}$, and third ventricle ${ }^{[16]}$. Of these "ectopic" locations, the basal ganglia/lateral ventricle has been the most common site ${ }^{[12]}$. Although the glial component is usually that of an astrocytoma, oligodendroglioma may represent the glial component or small foci of oligodendroglioma may be seen within a more typical neoplasm ${ }^{[22,23]}$. Although there is variation in markers used and results obtained by the different groups, others have also demonstrated evidence of multiple paths of differentiation ${ }^{[5-9,16]}$. The proliferative markers indicated low proliferative profile in $\mathrm{DNT}^{[5-7,9,24]}$. Cytologically, the principal tumor cells of the DNT are similar to those of the oligodendroglioma ${ }^{[12]}$. Both tumors may also share a similar microcystic architecture and delicate vascular network. The differentiation between them is very difficult in frozen material and in small biopsies, which lack the multinodular pattern of DNT. In addition, the presence of isolated neurons within the DNT can be interpreted as evidence of an infiltrating neoplasm (i.e., oligodendroglioma or fibrillary astrocytoma $)^{[12]}$. Perineuronal satellitosis, frequently a prominent feature in oligodendroglioma, is scant, if present at all, in the $\mathrm{DNT}^{[12]}$. In the context of the classic morphological 
appearance, usually immunohistochemistry stains are not required for the diagnosis; they have been of only marginal use in establishing the diagnosis ${ }^{[12]}$. The inconsistent immunoreactivity of GFAP in the OLCs contributed to misinterpretation as a glial neoplasm ${ }^{[12]}$. Granular perivascular immunoreactivity for synaptophysin in tumor neuropil, although a finding in $\mathrm{DNT}^{[7,24]}$, is nonspecific and often focal. Immunohistochemistry is useful in eliminating certain entities with characteristic immunohistochemical profiles from the differential diagnosis such as central neurocytoma and clear cell ependymomas. Central neurocytoma is diffusely and strongly positive for synaptophysin that is not a feature of DNT. Likewise, immunoreactivity for GFAP in the pseudorosettes of clear cell ependymomas distinguishes ependymomas from DNT. Fortunately, given the difficulties in histologic diagnosis, the radiological features of these lesions are distinctive ${ }^{[12]}$. In conclusion DNT are extremely slow growing masses, as evidenced by their ability to deform the overlying skull. Total or even subtotal resection has reportedly been curative; however the rare incidence of tumor recurrence necessitates long-term surveillance by neuroimaging. Although the characteristic clinical, radiological and histopathological features are well documented, full understanding of the nature of this lesion and its pathogenesis and molecular characteristics awaits further clinical experience. The recognition of this tumor is very important because it is a surgically curable lesion. Pathologists need to be familiar with the characteristic histopathological findings to avoid unnecessary overtreatment by radiotherapy or chemotherapy.

\section{References}

[1] Louis DN, Ohgaki H, Wiestler OD, Cavenee WK. WHO Classification of Tumors of the Central Nervous System. Lyon: IARC, 2007. N. pag.

[2] Plate KH, Wieser HG, Yasargil MG, Wiestler OD. Neuropathological findings in 224 patients with temporal lobe epilepsy. Acta Neuropathol (Berl) 1993; 86(5): 433-438.

[3] Wolf HK, Campos MG, Zentner J, Hufnagel A, Schramm J, Elger CE, Wiestler, OD. Surgical pathology of temporal lobe epilepsy. Experience with 216 cases. J Neuropathol Exp Neurol 1993; 52(5): 499-506.

[4] Prayson RA, Estes ML. Dysembryoplastic neuroepithelial tumor. Am J Clin Pathol 1992; 97(3): 398-401.

[5] Prayson RA, Morris HH, Estes ML, Comair YG. Dysembryoplastic neuroepithelial tumor: a clinicopathologic and immunohistochemical study of 11 tumors including MIB1 immunoreactivity. Clin Neuropathol 1996; 15(1): 47-53. 
[6] Raymond AA, Halpin SF, Alsanjari N, Cook MJ, Kitchen ND, Fish DR, Stevens JM, Harding BN, Scaravilli F, Kendall B, Shorvon SD, Neville BGR. Dysembryoplastic neuroepithelial tumor. Features in 16 patients. Brain 1994; 117(3): 461-475.

[7] Taratuto AL, Pomata H, Sevlever G, Gallo G, Monges J. Dysembryoplastic neuroepithelial tumor: morphological, immunocytochemical, and deoxyribonucleic acid analyses in a pediatric series. Neurosurgery 1995; 36(3): 474-481.

[8] Daumas-Duport C, Scheithauer BW, Chodkiewicz JP, Laws ER, Jr., Vedrenne C. Dysembryoplastic neuroepithelial tumor: a surgically curable tumor of young patients with intractable partial seizures. Report of thirty-nine cases. Neurosurgery 1988; 23(5): 545-556.

[9] Daumas-Duport C. Dysembryoplastic neuroepithelial tumours. Brain Pathol 1993; 3(3): 283-295.

[10] Daumas-Duport C, Varlet P, Bacha S, Beuvon F, Cervera-Pierot P, Chodkiewicz JP. Dysembryoplastic neuroepithelial tumors: nonspecific histological forms -- a study of 40 cases. J Neurooncol 1999; 41(3): 267-280.

[11] Daumas-Duport C, Varlet P. Dysembryoplastic neuroepithelial tumors. Rev Neurol (Paris) 2003; 159(6-7 Pt 1): 622-636.

[12] Baisden BL, Brat DJ, Melhem ER, Rosenblum MK, King AP, Burger PC. Dysembryoplastic neuroepithelial tumor-like neoplasm of the septum pellucidum: a lesion often misdiagnosed as glioma: report of 10 cases. Am J Surg Pathol 2001; 25(4): 494-499.

[13] Lellouch-Tubiana A, Bourgeois M, Vekemans M, Robain O. Dysembryoplastic neuroepithelial tumors in two children with neurofibromatosis type 1. Acta Neuropathol (Berl) 1995; 90(3): 319-322.

[14] Kirkpatrick PJ, Honavar M, Janota I, Polkey CE. Control of temporal lobe epilepsy following en bloc resection of low-grade tumors. J Neurosurg 1993; 78(1): 19-25.

[15] Honavar M, Janota I, Polkey CE. Histological heterogeneity of dysembryoplastic neuroepithelial tumor: identification and differential diagnosis in a series of 74 cases. Histopathology 1999; 34(4): 342-356.

[16] Leung SY, Gwi E, Ng HK, Fung CF, Yam KY. Dysembryoplastic neuroepithelial tumor. A tumor with small neuronal cells resembling oligodendroglioma. Am J Surg Pathol 1994; 18(6): 604-614.

[17] Whittle IR, Dow GR, Lammie GA, Wardlaw J. Dsyembryoplastic neuroepithelial tumor with discrete bilateral multifocality: further evidence for a germinal origin. Br J Neurosurg 1999; 13(5): 508-511.

[18] Cervera-Pierot P, Varlet P, Chodkiewicz JP, Daumas-Duport C. Dysembryoplastic neuroepithelial tumors located in the caudate nucleus area: report of four cases. Neurosurgery 1997; 40(5): 1065-1069.

[19] Guesmi H, Houtteville JP, Courthéoux P, Derlon JM, Chapon F. [Dysembryoplastic neuroepithelial tumors. Report of 8 cases including two with unusual localization] Neurochirurgie 1999; 45(3): 190-200.

[20] Kuchelmeister K, Bergmann M, von WK, Hochreuther D, Busch G, Gullotta F. Desmoplastic ganglioglioma: report of two non-infantile cases. Acta Neuropathol (Berl) 1993; 85(2): 199-204.

[21] Yasha TC, Mohanty A, Radhesh S, Santosh V, Das S, Shankar SK. Infratentorial dysembryoplastic neuroepithelial tumor (DNT) associated with Arnold-Chiari malformation. Clin Neuropathol 1998; 17(6): 305-310.

[22] Diepholder HM, Schwechheimer K, Mohadjer M, Knoth R, Volk B. A clinicopathologic and immunomorphologic study of 13 cases of ganglioglioma. Cancer 1991; 68(10): 2192-2201. 
[23] Prayson RA, Khajavi K, Comair YG. Cortical architectural abnormalities and MIB1 immunoreactivity in gangliogliomas: a study of 60 patients with intracranial tumors. $J$ Neuropathol Exp Neurol 1995; 54(4): 513-520.

[24] Hirose T, Scheithauer BW, Lopes MB, VandenBerg SR. Dysembryoplastic neuroeptihelial tumor (DNT): an immunohistochemical and ultrastructural study. $J$ Neuropathol Exp Neurol 1994; 53(2): 184-195. 


\section{ورم الخلايا العصبية ذات التشويه الجنيني التكوين: الوصف النسيجي و الصبغات المناعية}

\section{جودة أحمد المغزبي'،}

قسم علم الأمراض، 'جامعة الملك عبدالعزبز، و 'مستشفى الملك فيصل التخصصسي ومركز الأبحاث جـدة - المدلكة العربية السعودية

المستخلص. ورم الخلايا العصبية ذات التشويه الجنيني التكــوين يعتبر من الأور ام النادرة. النتخيص النسيجي الصحيح لهذه الأور ام

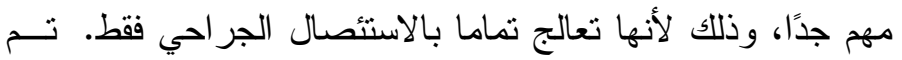

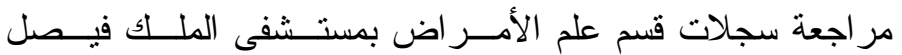
التخصصي ومركز الأبحاث - جدة - المملكة العربية الـسعودية، لكل حالات ورم الخلايا العصبية ذات النتويه الجنيني التكوين، وتم حصر خمس حالات من هذا الورم، وذللك خلال الفترة ما بين عام

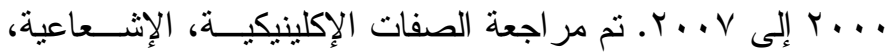
النسيجية و الصابغات المناعية. تم تشخيص خمس حالات من هذه

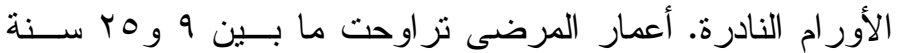

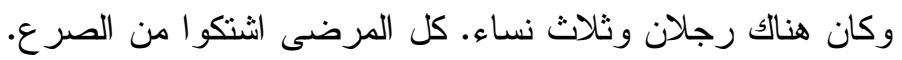
في مريض و احد كان وجود الورم في الفص الصدغي و المرضسى ونى

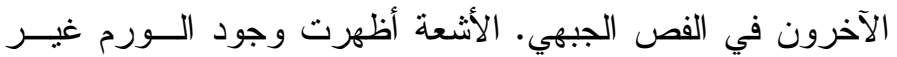

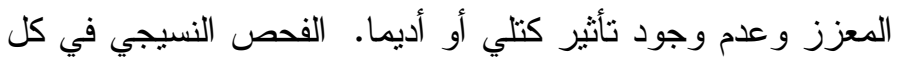
الحالات أظهر أن الورم يتكون من خلايا مشابهة لنسيج غـــينا.

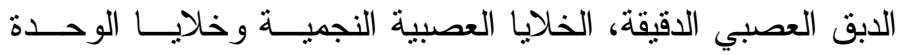
العصبية. الاستجابة للجر احة كانت ممتازة. التعرف على هذا الورم 
مهم جدًا، وذلك لأنه يتم معالجته تماما بالجر احة. يجب على أطباء علم الأمر اض أن يكونوا على دراية تامة بالصفات النسيجية لهــذا الورم، وذللك لتجنب العلاج الإشعاعي و الكيماوي بدون حاجة. 